\title{
IMPROVING THE MECHANISM OF COLLECTING CERTAIN TAXES IN UKRAINE AS MEASURES FOR THE EUROPEAN MODERNIZATION: LEGAL ASPECT
}

\author{
Oleksandr Holovko', Tetyana Kaganovska², Galina Rossihina ${ }^{3}$
}

\begin{abstract}
The aim of the article is to study the methodological and theoretical principles of improving the legal regulation of the taxation system in Ukraine in the European integration context. Determination of the doctrinal basis for the implementation of the tax function of the state and its legal consolidation from the standpoint of the fundamental principles of the law allows carrying out a comparative legal analysis of taxation in the developed countries of Europe and the world (particularly indirect one). Methodology. The research is based on the theoretical and legal substantiation of the social content of tax activities in the state, and it is also based on the understanding of the dialectical relationship between tax processes and the functioning of social and legal systems in general. A systematic analysis of the tax activity of the state in the context of humanism, justice, freedom, equality, rule of law is carried out. On this basis, the legal nature of the regulation of the value-added tax is revealed. Results. The basic theoretical and legal bases of measures on improvement of the taxation system are determined as a result of the study from the position of its legitimation among citizens and stimulation of their purchasing power and development of productive forces of the Ukrainian economy. Practical impact. The definition of directions for perfection and humanization of tax legislation in Ukraine allows making a conclusion about the volume of the tax burden on the consumer and proposing optimal rates of value-added tax rates.
\end{abstract}

Key words: social nature and legal nature of taxation, equity of taxes, value added tax, tax pressure, optimization of tax rates.

JEL Classification: H21, H24, H26, K34

\section{Introduction}

The existence of state and law as an unalienable, most important, universal social institution is impossible without the finances and implementation of the tax function. Since the time of the emergence of state and law, society pays for its stability, and citizens pay for the security and non-conflict of their existence. With its development, the state began to accumulate funds not only for the maintenance of its apparatus and armed forces but also for social tasks. When the rationalist philosophical and legal reflection in Ancient Greek had appeared, then the question of the subordination of society and its members to the law and rules, but not to the arbitrariness of some individual rulers arose. Plato's statements about the rule of law, but not people are rather well-known, as well as Aristotle's statement regarding the subordination of citizens to laws as the main criterion of legitimacy (correctness) of the form of government (Kovalchuk, 2011). Aristotle paid a lot of attention to the question of the equitable distribution of social resources, which main way of accumulation and increase at all times was a fiscal source. After all, it is the financial issues and the taxation problem - that is the issues, on which the citizen constantly contacts the state, judges it, perceives or does not perceive its legitimacy and justice. Problems of legal regulation of taxation and imposition of taxes were the driving force through the history of the state and the rights of developed European countries.

So, the legality of the bases of the taxation, a guarantee from any increase in fiscal pressure became one of the main goals of the English revolution and civil war of the middle of the 17th century (the establishment of taxes by representatives of the legislature in the parliament, and not the king's arbitrariness). One of the main reasons for the liberation war and the revolution of the second half of the eighteenth century in North America and the formation of the United States was an arbitrary

\footnotetext{
Corresponding author:

${ }^{1}$ V.N. Karazin Kharkiv National University, Ukraine.

E-mail: golovkoom1967@ukr.net

${ }^{2}$ V.N. Karazin Kharkiv National University, Ukraine.

E-mail: tekaganovskaya@gmail.com

${ }^{3}$ V.N. Karazin Kharkiv National University, Ukraine.
} 
increase and the imposition of taxes on the colonies by the English crown - stamp duty, the excise tax on tea and other goods. The so-called bourgeois revolutions over the next half-century, since the Great French Revolution, broke out as a result of the injustice of class feudal taxation. These revolutions had a protest against the injustice and the unlawful nature of taxation as one of the main factors.

\section{The state of scientific research}

Recognition and non-recognition of the state by citizens, its support or vice versa, protest movement, often are based on the effectiveness, social targeting of the tax policy of the state and its legal consolidation. Moreover, the civilizational peculiarities of any society are based on the understanding and perception of legal personality, particularly, in the field of taxation. Its extreme expressions are rooted in the history of the ancient Eastern society, collective, communal personality, subordination to collective, caste-ridden, and state legal personality. This tradition has gone through our time through Hinduism, Confucianism, the ideology of the Golden Horde and other eastern despots. Western tradition - is a developed individualism, individual legal personality, the value of a full personality, which is coming from the ancient world that is full citizenship in the policies of ancient Greece and the development of private property and related property relations in ancient Rome (Kalynovskyi, 2008). Legal personality was historically formed not only in the field of state law and the existence of civil rights but also in the taxation field. Western tradition is the personality of the subject of taxation, oriental is the collectivity, community. Ukraine, after the annexation of its territory and the elimination of autonomy by the Russian Empire at the end of the eighteenth century, had differed by the prevalence of an inherited form of peasant land tenure with individual taxation. We mean that the western tradition of legal personality was more prominent. The subject of land use and, accordingly, taxation was the peasant community with its circular guarantee on the ethnic Russian lands. That is, there were mostly manifestations of the Eastern tradition (Holovko, (2006). However, in the eastern part of the Ukrainian lands in the Russian Empire, the land community as a land tenure subject also took place. The collapse of collective legal personality in the field of land management and taxation was the main goal of Stolypin's agrarian reforms of 1906-1911.

\section{Presentation of the main material}

So, at the beginning of the twentieth century, Ukraine had a stable legal tradition in the field of taxation, which was really close to European ones. That is why even today, in the conditions of the decisive and responsible movement of Ukraine towards European community, its society has historic law-conscious and mental orientations, which were formed for centuries. These orientations were directed to the western tradition of tax perception and the legal basis for their collection. At the same time, measures of integration and reformation in the fiscal sphere should take into account all the peculiarities of the transitional period (today Ukraine can reasonably be considered as a social system of transitive states and rights (Matvieieva, 2015)). It is also important to fulfil the financial sovereignty of Ukraine in the context of improving its tax system and its legal basis (Bytiak, Yakoviuka, 2010). An intellectual and methodological discussion of the jusnaturalist and juspositivistic understanding of the law, including tax law, was taken place in Western legal tradition. This discussion has reached such a level of scientific compromises for today when even a positivist understanding of the legal world admits the existence and necessity of morality (Fuller, 1999), values in the law and the corresponding legal principles.

Taking into account the fact that the main source of formation of the revenue part of the state budget in Ukraine is taxes, we can say that the issue of legal regulation of taxation is considered to be the most urgent question. That is why, at the present stage, tax reforms and transformations take a prominent place in the processes of improving market relations. The process of restructuring the tax system of Ukraine, analysis of the peculiarities of legal regulation of taxes and fees gets a great importance. Except for actually legal and technical moments and aspects, it is important to realize the most common general principles of law, which are recognized either in Romano-Germanic, or AngloAmerican type legal systems. In this article, we study the system of fundamental principles of law in terms of the concept of S. Pogrebnyak (Pohrebniak, 2008).

Today, in many studies of domestic legal science, we can observe certain remnants of the doctrinal legal understanding of the Soviet era, when the principle of humanism was not so important. The volume and tasks of this article do not require a detailed analysis of this issue, but we consider it necessary to start with it. However, the traditional primacy of justice has an anthropological character in the list of principles. That is why, the implementation of the principle of humanism leads to the fairness of the system of tax deductions, benefits and tax exemptions - the fact that, in the case of abuse and noncompliance, leads to a decrease in the legitimate rationale of the state and its legal system. And in practice, it leads to a variety of corruption violations. Traditionally, the principle of equity in tax law is expressed in proportional progressively proportional taxation and the establishment of taxes on luxury, and so on.

Equality is the principle and condition of taxation, which is enshrined in law. It is also connected with the fairness of taxes. The consistent implementation of 
this principle makes the payer morally disciplined and confident that law-making and law-enforcement practice do not make unlawful exceptions to this principle and they do not allow that among subjects, particularly, in economic management or business, equal to each other, there is someone "more equal" (using the famous phrase of G. Orwell from Animal Farm). In our opinion, the principle of freedom is realized in tax law more indirectly. After all, paying a tax is a duty and not a right, and, at the same time, it is an important feature and characteristic of a free person, it is a manifestation of his freedom. However, on the one hand, it is the realization of freedom of social activity, primarily economic, that is, it is the implementation of social and economic rights and freedoms of man and citizen. Besides, if the right is legalized and provides freedom, and the state is an instrument and mechanism for its achievement (at least when we are talking about the rule of law with a developed civil society), then collecting of taxes is a material factor in ensuring this freedom of man and citizen.

A special attention is paid to the principle of the rule of law. A few of the general principles of law have received such varied, high-quality, and various scientific legal literature in recent decades. The ineffectiveness of determining its content in the formal-dogmatic field leads to a phenomenological characteristic, showing through manifestations and signs "an integral approach", according to P. Rabinovich (Tatsii, Sviatotskyi, Maksymov, 2013). Among the eight main features of the principle of the rule of law, which were formulated by M. Kozyubrov, the establishment of a democratic, humane, fair system of taxation in any state that positions itself as a legal (in our case it concerns primarily Ukraine) can be applied to all eight (Tsvik, Petryshyna, 2008). They have either a general theoretical or a special applied value. As for the last aspect, we will list a number of separate positions.

First, this is a limitation of the discretionary powers of the authorized tax authorities. It should be one of the main directions of reforming the organizational and legal basis of taxation in Ukraine. Second, it is the application of the principle of certainty. Since in most cases the taxation issues concern specific citizens or their associations, tax legislation should be as clear as possible in determining the grounds, objectives, and content of tax regulations. It should be also noted that as well as in other social spheres, judicial authorities should play a special role in the implementation of the principle of certainty in tax law. So, judicial reform and increasing the efficiency of the judiciary in Ukraine have big importance for improving the tax system in the state. It is logical that the independence of the court and judges is also connected with it. The principle of proportionality is also connected with the previous ones, and it is extremely important for the fairness of taxation and its stable efficiency. This applies both to the definition of tax rates and the provision of mandatory taxes and levies, which are limited by law. Directing of sanctions tendencies for tax offenses from the sphere of personal punishment (first of all imprisonment) to financial and property, reimbursement of losses to the budget, etc. correspond to the previous principle also. And do not forget such a component of the rule of law as a principle of legal security and protection of trust. The taxpayer must be confident in the stability of his legal position and in the fact that it will not deteriorate. Essentially, it is also close to the principle of irreversibility of laws and other normative legal acts (Article 58 of the Constitution of Ukraine).

The mentioned principles are not only the general theoretical basis for the formation of the foundations of tax legislation and the development of the field of financial law in independent Ukraine. Their implementation in specific legal orders and acts of application of the law has direct practical value and is the only possible way of European integration in the field of taxation.

Taxes are not only the main source of budget revenues but also the regulator of public proportions; it is a guarantor of social protection of citizens and the creation of a modern material basis of state sovereignty (as well as the development and efficiency of local government).

The world experience in the development of tax systems shows that its doctrinal substantiation has a real importance. The Age of Enlightenment gave the impetus for these research processes, as well as in other areas of knowledge. So, A. Smith in his scientific work "An Inquiry into the Nature and Causes of the Wealth of Nations" formulated the principles of taxation for the first time (one of them is the principle of justice). He also defined tax payments, their place in the financial system of the state, and also emphasized the fact that taxes for the payer were an indicator of freedom, but not slavery (Smith, 2018). In the nineteenth century in Europe, there was the establishment of scientific and theoretical views on the nature, problems and methods of taxation, and compliance with the legal form of implementation and enforcement. That is, the general, public interest in the necessity of collecting taxes was realized by the layers of the population. And the awareness of the state's interests regarding the fiscal coverage of the revenue side of the budgets had led, in turn, to the conclusion that the legal regulation of relations in the field of taxation had become necessary. It is important to note that legal consciousness and legal culture are internal, intellectual settings that mainly affect the effectiveness of legal regulation, we mean achievement of the goals, which are pursued by the legislator by the publication of relevant norms.

Like other branches of law, a financial law is an embodiment in the form of regulatory regulations of the economy, particularly, the financial policy of the state. As P. Gaudemet thinks, this process has two main 
aspects. On the one hand, the relationship between political forces and the political structure of a country largely determines the financial policy of this country. On the other hand, political events, especially if they take the form of a crisis, also affect public finances and result in a financial mechanism (Gaudemet, 1978). The relationship between tax policy and tax law is expressed in two ways: a) through tax policy, the main objectives of taxation are implemented, that is why its research allows us to get a better idea of the subject of regulation of tax law; b) tax policy provides tax reforms, which are registered by the corresponding financial laws (Kozyrin, 1993). The effectiveness of tax policy largely depends on what special (tax or tax law) principles the state puts in its bases, particularly: the ratio of direct and indirect taxes, the breadth of tax privileges, their nature and purpose, discreteness or continuity of taxation, etc. In its turn, the main concepts of tax policy are an effective tax burden, tax capitalization, optimal taxation, and tax pressure.

For nowadays, according to the norms of the Tax Code of Ukraine, the tax legislation of Ukraine is based on the following special principles: the universality of taxation, social justice, fiscal sufficiency, stability, efficiency, and neutrality of taxation, etc. So, under the principle of social justice (as the embodiment of the fundamental principle of justice), the legislator understands the principle of setting taxes and fees in accordance with the paying capacity of taxpayers (Podatkovyi kodeks Ukrainy).

As reasonably $\mathrm{R}$. Tsippelius states, the right has to regulate human behaviour in such a way that all benefits (values) and burdens (costs, liabilities) should be distributed fairly, and conflicting interests should be satisfied in accordance with their weight and significance; those who commit a punishable act should receive a proper remuneration for them. So, R. Tsippelius insists that justice should prevail in resolving the conflicts, which may arise in society (Tsyppelius, 2004).

However, an estimate to a certain extent, sometimes subjective nature of understanding and perception of justice, the need to take into account a large number of individual circumstances that are difficult to take into account in the legislation (considering dynamism of constantly growing social processes) complicate its full achievement in various social spheres. This can also be applied to tax law (Sotov, 1998).

Tax pressure is one of the main characteristics of tax policy. This concept characterizes the role of taxes in the life of society at the macroeconomic level. It can be defined as the ratio of the total amount of tax collections to the aggregate national product. If we are talking about a particular taxpayer, then tax pressure reflects the proportion of its total income deducted from the budget. In the tax doctrines of the West, an additional and sufficiently pronounced indicator of the effective tax rate is used to calculate the tax pressure. This is a fraction of the tax in the total taxable income of the payer. It should be mentioned that the tax pressure, which can be measured by the indicator of the full rate of taxation, is very high in Ukraine compared to European countries. So, recently, legal regulation of the permanent increase of excise taxes, taxes on transport, property - are in the prerogatives of tax policy. The tax burden, taking into account social charges in Ukraine for the poor, belongs to the highest in the world, with the simultaneous existence of a favourable tax regime for the rich part of the population. At the same time, obviously, the tactical fiscal task prevails over the strategy of stimulation of production and circulation, the growth of taxable income.

Thus, the Law of Ukraine as of December 7, 2017, "On the State Budget of Ukraine for 2018" establishes the minimum wage: in monthly amount from January 1 - $3723 \mathrm{UAH}$; in hourly terms from January 1 is 22.41 UAH, living wage for able-bodied persons: from January 1, 2018 - 1762 UAH, from July 1 - 1841 UAH, and from December 1 - 1921 UAH (Pro Derzhavnyi biudzhet Ukrainy na 2018 rik: Zakon Ukrainy). The tax social benefit is $881 \mathrm{UAH}$ for any payer in 2018 . The maximum salary, to which the tax social benefit can be applied, is equal to $2470 \mathrm{UAH}$ in 2018. Starting in 2016, the contribution from the salary of an employee is not carried out. For example, the employee was charged 3723 UAH for the full working month - it is a minimum wage. The tax social privilege cannot be applied to it, as it exceeds the maximum amount of income that gives the right to a tax social benefit - it is $2470 \mathrm{UAH}$. The tax on personal income will be $18 \%$ (670.14 UAH), the military fee will be $1.5 \%$ (55.85 UAH), the single contribution is $22 \%$ ( $819.06 \mathrm{UAH})$. The maintenance will be equal to $725.99 \mathrm{UAH}$, that is, the employee will receive only $2997.01 \mathrm{UAH}$. Taking into account the taxation of consumption with a value-added tax, the net income of the payer in Ukraine is actually $2500 \mathrm{UAH}$. And this is without taking into account the payment of excise taxes on fuel, alcohol, tobacco, taxation of land, real estate, etc. As a result, an average citizen pays at least $40 \%$ of the income received, and the wealthier strata about $30 \%$ or even less. That means that taxes in Ukraine are much higher than in Europe for the poor and lower segment of the people than for the wealthy. In this case, in the developed social European states, socially unprotected citizens (whose annual income is less than 9000 euros) have a negative tax rate. That means that they have a net subsidy, which is received from the state in a larger amount than the taxes paid. Ukraine has no such tax practice.

Thus, the concept of progressive scales of taxation as humane and just exists mainly on the doctrinal level of economic and legal research in Ukraine. And the fiscal practice shows the opposite. At the beginning of the 2000s, the progressive scale of personal income tax (personal income tax) already existed in Ukraine. Its rate varied from 10 to $50 \%$, depending on the level of income. However, in order to unshadow the economy in 2004, 
the legislator changed the basis of taxation of individuals' incomes by introducing a flat scale. This measure did not give a proper financial effect. And since 2007 the volumes of withdrawal of capital abroad and, consequently, the concealment from taxation are increasing.

Keynesian approach lies at the heart of the progressive rate of income tax. In this approach, the main stimulus of economic activity is considered the expansion of solvent demand and stimulation of production. This approach operates in a number of highly developed countries, such as: the United States, Great Britain, France, Denmark, as well as China. In the United Kingdom, the income tax on individuals does not come from aggregate income, but from parts (schedules) depending on the source of income. Each schedule is taxed in a special order. The personal discount today is 4615 pounds sterling. There are three rates of income tax (after taking into account all benefits): up to 1960 pounds - 10\%, 1961-30500 - 22\%, and higher $40 \%$. In China, there is a nine-level progressive tax rate from 5 to 45\% (Popova, Drozhzhina, Maslov, 2011). In the United States, taxes are also proportional to income with little progressiveness (approximately 25 to $50 \%$ ) (Popova, Drozhzhina, Maslov, 2011). At the same time, most of the tax pressure falls on the richest citizens. Implementation of approaches by $\mathrm{D}$. Keynes in practice allows with the help of tax regulation to redistribute resources in the state (Majburov, 2011).

One of the main issues in the economic theory of taxation and the doctrine of tax law is the ratio of direct and indirect taxes. At the present stage of development of the tax system of Ukraine, there is a sufficiently developed group of indirect taxes. They are taxes on consumption and they are implemented in goods prices. The terms of their realization and payment practically coincide. Administration of direct taxes is more complex and more adequately reflects the development of productive forces. Direct taxation is more in line with the principles of justice, humanity, and equality and has a higher ability to influence the economy and stimulate it. The legislation on direct taxes has to correspond to the conditions of social and economic development (Zhvaliuk, 2001).

The modern indirect taxation is based on the experience of the functioning of the previous forms, first of all, duties and excises. The emergence of a value-added tax is due to the corresponding stage of economic development. The countries of Europe switched to this tax mainly in the period from 1967 to 1973, after prolonged existence of other (reversible) taxation. In Western European states, it began to appear as a mechanism, which was aimed to slow down consumption, especially at a stage of significant growth in production. The French economist M. Lauré (see in detail: 20) was first, who described the scheme of the value-added tax in 1954. This tax even now brings up to $45 \%$ of all tax revenues in France. The attitude towards value-added tax in different economically developed countries differs. In Italy, it replaced the turnover tax (1973) and more than 20 excises and provides about two-thirds of tax revenues to the budget. However, the attitude towards this indirect tax is more moderate in leading European countries. In the UK, it was legally secured in 1973, instead of the wholesale tax. However, its implementation in this state has a rather complicated mechanism. In Sweden, the value added tax is levied on the commercial sale of goods and services. In 1969, the tax on artificial sales was replaced by it. It accumulates up to $14 \%$ of tax revenues in Sweden. At the present stage, the value-added tax is one of the most important components of the tax systems of 42 states (17 European ones). The share of this tax accounted for about $13.8 \%$ of tax revenues and 5.5\% of GDP. Along with this, there are countries, which are rather well developed in social and economic spheres, where the value-added tax has not taken a significant place in the tax system. Direct taxes are dominant there. These are, in particular, the United States and Japan.

Value Added Tax is one of the few in the tax system of Ukraine, which fully goes to the State Budget. It is important to determine its bid. In European countries, there are lower, higher, and standard rates. The first one is usually applied to food products and medical services, the latter to luxury items. There are also some cases when can be the complete exemption of certain goods and services from taxation by setting a zero rate or its absence. Such methods eliminate the taxation at the sale of goods or service to the end user. In the EU countries, the zero rates are also set for export goods. EU unification implies the use of the standard valueadded tax rate of $18.6 \%$ and the reduced value of $5.5 \%$. In Ukraine, by the Decree of the Cabinet of Ministers of Ukraine "On Value Added Tax" as of December 26, 1992, the rate was set at 20\% (Pro podatok na dobavlenu vartist, 1993). In 1993, the Law of Ukraine "On the State Budget of Ukraine for 1993" increased the tax rate to $28 \%$ (Pro Derzhavnyi biudzhet Ukrainy na 1993 rik, 1993). In 1997, the Law of Ukraine "On Value Added Tax" restored the rate of $20 \%$, which was the main and was distributed by turnover, which was calculated at prices excluding value-added tax. If the prices and tariffs that included this tax were used, then the rate of $16.67 \%$ (Pro podatok na dodanu vartist, 1997) was applied. Today, the value-added tax rate in Ukraine has three levels: the basic rate is $20 \%$, preferential is $0 \%$ (as a rule, for goods oriented to export) and 7\% (delivery in the customs territory of Ukraine and import to the customs territory of Ukraine of medicines, which are allowed for production and use in Ukraine, and which are included in the State Register of Medicinal Products. Besides, delivery of medical products, which are included in the State Register of Medical Equipment and Medical Devices or correspond to the requirements of the relevant technical regulations, which can be confirmed 
by the compliance document, and which are allowed for placing on the market or putting into operation and use in Ukraine, etc.).

A large number of scientists believe that the valueadded tax is regressive in its legal nature and very costly in management, it requires a large tax unit, significant overheads of business entities. It should be noted that in most countries $60-70 \%$ of revenues from this tax, they receive from $10-15 \%$ of payers - entrepreneurs. The worldwide experience of charging value added tax suggests that due to its administrative complexity and high fixed costs its optimal rate should be 15 or even $10 \%$. The rate should be, if not the only, and then expediently (minimum) differentiated. This will simplify administration and reduce tax delinquency (avoidance of payment). Such amount of tax is also due to the fact that the rate at the level of $20-28 \%$ has a negative effect on high-tech enterprises, as well as it stimulates inflationary processes in general. This is due to the fact that the value added tax is a tax on the final consumer and at its high rate, there is an increase in prices. The purchasing power of the population is decreasing. A high rate of value-added tax results in high spending on the end user - we mean broad segments of the low-income or unsecured population.

Besides, we need to mention that today Ukraine has formed the proper organizational andlegal preconditions for optimization and socialization of the value-added tax. The technical level of the taxpayer information database has increased; the material and technical base and personnel qualifications have improved, as well as the legal and regulatory framework of the State Fiscal Service, the State Treasury Service, and the Financial Monitoring Service was also improved.

\section{Conclusions}

That is why, in our opinion, preconditions for harmonization of the legislation of Ukraine, which regulates the tax system, have already emerged. The observance of the fundamental principles of law, as well as the basic principles of special tax law, will ensure the achievement of the following results:

- ensuring the unalienable rights, freedoms, and legitimate interests of the person;

- achievement of a fair distribution of the tax burden by determining its progressive-proportional size in the sphere of both direct and indirect taxation, its transfer from less socially well-founded on richer members of society;

- harmonization of direct and indirect, centralized and local taxation; using the experience of the most developed European countries in the field of legal regulation of taxation;

- the increase of legitimacy of the state in the eyes of its citizens - taxpayers, the consciousness of payment of taxes, understanding of the targeted direction of accumulation as a result of taxation of state resources; - stimulation of the economic activity of business entities in Ukraine, development of GDP, an increase in the index of the standard of living of a person, and consequently, an increase in absolute volumes of tax revenues with a decrease in their relative size, that is, tax rates.

We propose to establish a unified two-tier approach to the determination of the rate by applying similar approaches to one of the most important components of the taxation system - the value-added tax: we mean, the general (base) rate in the amount of $15-17 \%$ and the preferential $5-7 \%$ (sale of medicines, baby food products, etc.). In case of harmonization of other types of tax revenues, ensuring an appropriate and necessary balance between the funds of the State and local budgets, a high legal technique for the implementation of relevant legislative and other regulatory legal acts - such an approach will positively affect the economic growth in Ukraine, the standards of living of citizens and ensuring the social purpose of the state.

\section{References:}

Kovalchuk, V. B. (2011). Legitymnist derzhavnoyi vlady v pravovij teoriyi ta derzhavno-pravovij praktyci: Monografiya [Legitimacy of state power in legal theory and state-legal practice: Monograph]. K.: Logos.

Kalynovskyi, Yu. Yu. (2008). Pravosvidomist ukrainskoho suspilstva: geneza ta suchasnist: Monohrafiia [Legal awareness of Ukrainian society: genesis and modernity: Monograph.]. Kh.: Pravo.

Holovko, O. M. (2006). Aparat upravlinnia derzhavnymy finansamy Rosiiskoi imperii v Ukraini u kintsi XVIII na pochatku XX st.: orhanizatsiino-pravovi zasady diialnosti: Dys. na zdobuttia nauk. stupenia doktora yurydychnykh nauk [The apparatus of public finance management of the Russian Empire in Ukraine at the end of the XVIII - early XX centuries: the organizational and legal principles of activity: Dis. for obtaining Doctor of Law]. Kh.: KhNUVS.

Matvieieva, L. H. (2015). Tranzytyvnist u pravovii sferi: Monohrafiia [Transitivity in the legal sphere: Monograph]. K.: Yurinkom Inter.

Bytiak, Yu. P., Yakoviuka, I. V. (2010). Derzhavnyi suverenitet: teoretyko-pravovi problemy: Monohrafiia [State sovereignty: theoretical and legal issues: Monograph]. Kh.: Pravo.

Fuller, L. (1999). Moral prava [Morality of the law]. Nauk. vydannia. K.: Sfera.

Pohrebniak, S. P. (2008). Osnovopolozhni pryntsypy prava (zmistovna kharakterystyka): Monohrafiia [Fundamental principles of law (content characteristic): Monograph]. Kh.: Pravo. 
Tatsii, V. Ya., Sviatotskyi, O. D., Maksymov, S. I. (2013). Pravova doktryna Ukrainy: u 5 t. T. 1: Zahalnoteoretychna ta istorychna yurysprudentsiia [The legal doctrine of Ukraine: 5 t. T. 1: General theoretical and historical jurisprudence]. Kh.: Pravo.

Tsvik, M. V., Petryshyna, O. V. (2008). Pravova systema Ukrainy: istoriia, stan ta perspektyvy: U 5 t. T. 1: Metodolohichni ta istoryko-teoretychni problemy formuvannia i rozvytku pravovoi systemy Ukrainy [The legal system of Ukraine: history, state and prospects: $5 \mathrm{t}$. T. 1: Methodological and historical-theoretical problems of the formation and development of the legal system of Ukraine]. Kh.: Pravo.

Smith, A. (2018). Doslidzhennia pro pryrodu i prychyny bahatstva narodiv [An inquiry into the nature and causes of the wealth of nations]. K.: Nash format.

Gaudemet, P. M. (1978). Fynansovoe pravo [Financial law]. Moskva: Prohress.

Kozyrin, A. N. (1993). Nalogovoe pravo zarubezhnyh stran: voprosy teorii i praktiki [Tax law of foreign countries: issues of theory and practice]. Moskva: Manuskript.

Podatkovyi kodeks Ukrainy [Tax Code of Ukraine]. Vidomosti Verkhovnoi Rady Ukrainy (VVR). 2011. № 13-14, № 15-16, № 17. St. 112.

Tsyppelius, R. (2004). Yurydychna metodolohiia [Legal methodology]. K.: Referat.

Sotov, A. M. (1998). Chto est spravedlivost? (realizaciya principa spravedlivosti v Nalogovom kodekse i dejstvuyushchem nalogovom zakonodatelstve) [What is justice? (realization of the principle of justice in the Tax Code and the existing tax law)]. Vash nalogovyj advokat. Vyp. 4.

Pro Derzhavnyi biudzhet Ukrainy na 2018 rik: Zakon Ukrainy (2018) [About the State Budget of Ukraine for 2018: Law of Ukraine]. Vidomosti Verkhovnoi Rady. № 3-47. St. 26.

Popova, L. V., Drozhzhina, I. A., Maslov, B. G. (2011). Nalogovye sistemy zarubezhnyh stran: ucheb.-metod. posobie [Tax systems of foreign countries: methodologica book]. M.: Delo i Servis.

Majburov, I. A. (2011). Teoriya i istoriya nalogooblozheniya [Theory and history of the taxation]. Moskva: YUNITI-DANA.

Zhvaliuk, V. R. (2001). Podatkovi orhany Rosiiskoi imperii v Ukraini u druhii polovyni KhIKh - na pochatku XX st.: Orhanizatsiino-pravovi zasady diialnosti: Monohrafiia [Tax authorities of the Russian Empire in Ukraine in the second half of the nineteenth and early twentieth centuries: Organizational and legal principles of activity: Monograph]. K.: Atika.

Lauré, M. (1954). La politique fiscale. Paris: Presses Universitaires de Frances.

Pro podatok na dobavlenu vartist: Dekret Kabinetu Ministriv Ukrainy (1993) [About the Value Added Tax: Decree of the Cabinet of Ministers of Ukraine]. Vidomosti Verkhovnoi Rady Ukrainy. № 10. St. 78 .

Pro Derzhavnyi biudzhet Ukrainy na 1993 rik: Zakon Ukrainy (1993) [About the State Budget of Ukraine for 1993: Law of Ukraine]. Vidomosti Verkhovnoi Rady Ukrainy. № 20. St. 212.

Pro podatok na dodanu vartist: Zakon Ukrainy (1997) [About the Value Added Tax: The Law of Ukraine]. Vidomosti Verkhovnoi Rady Ukrainy. № 21. St. 156. 